\title{
Efficacy of Shunthi-Lodhra Churna in the Management of Asrigdara (DUB)
}

\author{
Research Article
}

\section{Swatirekha Mohapatra $^{1 *}$, Rachana Gupta ${ }^{2}$, Kalpana Sharma $^{3}$, Gyanendra Datta Shukla ${ }^{4}$}

\author{
1. PG Scholar, . 2. Assistant Professor, 3. Professor, 4. Assistant Professor \\ Department of Prasuti Tantra \& Stree Roga, Rishikul Campus, \\ Uttarakhand Ayurveda University, Haridwar, Uttarakhand, India.
}

\begin{abstract}
Objectives: The most common bleeding disorders in women are described as Asrigdara in Ayurveda, characterized by Pradirana (excessive excretion) of Raja (menstrual blood). It can be correlated to 'Dysfunctional Uterine Bleeding' in modern medicine. In modern medicine hormonal therapy, anti-prostaglandins \& antifibrinolytic agents have not proven their definitive efficacy in spite of high costs; their side effects have led to hormonal imbalances. Methods: In order to overcome the above abnormalities, we conducted a clinical trial for 90 days on 30 patients of age group 18-45 yrs. We administered Shunthi Churna (2 gms.) and Lodhra Churna (3gms) mixed with Sharkara (5 gms.) i.e. total (10gms) thrice daily with cold water, after food. Two observations were taken, $1^{\text {st }}$ after 45 days of treatment and the $2^{\text {nd }}$ one after completion of treatment on various parameters like amount and duration of blood loss, inter-menstrual period, passage of clots and pain during menstruation. Results: Based on the parameters studied, we observed $60 \%$ of patients improved moderately, $36.7 \%$ showed mildimprovement, 3.3\% showed marked-improvement in different symptoms. The results are highly significant on most parameters. Conclusion: Drug formulation Shunthi Churna and Lodhra Churna with Sharkara, proved to be effective in treating most of the symptoms of Asrigdara.
\end{abstract}

Keywords: Asrigdara, Dysfunctional Uterine Bleeding, Shunthi Churna, Lodhra Churna.

\section{Introduction}

Dysfunctional uterine bleeding (DUB) is defined as a state of excessive abnormal uterine bleeding without any clinically detectable organic pelvic pathology. The abnormality may be in frequency, duration or amount or combination of all (1). Normal menstrual cycle varies from 21-35 days with the bleeding phase of 4-6 days with an average loss of 35$45 \mathrm{ml}$ of blood (2). Abnormal menstrual cycle is defined as any deviation from the aforesaid. The disease Asrigdara explained in Ayurveda may be closely co-related with the condition Dysfunctional uterine bleeding of contemporary medical science.

According to Acharya Charaka, if the menstrual cycle turns to be abnormal due to Pradirana (excessive secretion) of Raja, it is termed as Pradara (3).

According to Acharya Sushruta, excessive and prolonged bleeding during menstruation or even in inter -menstrual period, different from the features of normal menstrual blood is called "Asrigdara" (4).

In women it is a significant healthcare problem in

*Corresponding Author:

Swatirekha Mohapatra, M.S.

Department of Prasuti Tantra and Stree Roga,

Uttarakhand Ayurveda University,

Rishikul Campus, Haridwar,

Uttarakhand, India 249401

Email id: mohapatrasd123@gmail.com the developed world (5) due to the increased stress. Between 25 - 58\% of women participating in the WHO study reported having excessive bleeding per vaginum in the past three months $(6,7)$. One in 20 women aged 30-40 consults their general practitioner every year complaining of heavy uterine bleeding (8). This potentially puts them under distressing condition in their social work place.

The Nidanas are responsible for Asrigdara as described by Charaka are mostly Pitta Vardhaka (9). Without the influence of Vata Dosha, Yoni never gets vitiated; so all Yoni Vyapads \& Artava Vyapads are because of Vata Dosha (10). Acharya Charaka also explained it as a symptom of Pittavrita A panavayu (11).

Various treatments like hormonal therapy, antiprostaglandins \& anti-fibrinolytic agents are available in modern health science. Many side effects have been observed because of the medication and hysterectomy lead to hormonal imbalance and psychological upset in young fertile women. So keeping this in mind we took Ayurvedic drug trial, which are non-hormonal and safe that could provide effective alternative for Asrigdara.

We have selected 'Shunthi-Lodhra Churna with Sharkara' which has been mentioned in "Yoga Ratnakar" due to its contents, cost effectiveness and disease healing properties (12).

The combinatorial formulation selected for our treatment based on the following properties. Shunthi has property of Kaphavata Nashana and Shula Prashamana 
(13), Lodhra has Rakta Sthambhana and Garbhasaya Shothahara properties (14) and Sharkara for its Vata, Pitta, and Rakta Doshahara properties (15). So here we attempted to evaluate the efficacy of Shunthi-Lodhra Churna with Sharkara in the management of Asrigdara w.s.r. DUB.

\section{Objectives of the study}

- To evaluate the effect of Shunthi Churna and Lodhra Churna with Sharkara in the patients suffering from Asrigdara, on various scientific parameters.

\section{Materials and Methods}

Patients attending to the O.P.D of Prasuti Tantra \& Stree Roga department, Uttarakhand Ayurved University, Rishikul Campus, Haridwar, were randomly selected based on the following inclusion and exclusion criteria's.

\section{Inclusion criteria}

1. Patients aged between $18-45$ years, with complaints of excessive bleeding per vagina during menstruation either in amount or in duration or both or during inter-menstrual period for 3 consecutive menstrual cycles.

2. Patients who are using neither oral contraceptive pills nor IUCD for contraception or hormonal treatment.

\section{Exclusion criteria}

1. Patient suffering from DUB complicated by nonresponding anemia and confirmed for surgical interventions.

2. All patients expected to have any organic involvement or those who cannot be labeled as DUB.

3. Patients considered having extra genital factors for the uterine bleeding like thyroid dysfunction, liver dysfunction, coagulation disorders etc.

4. Patients giving history of recent delivery or abortion.

5. Patient having infections such as candidiasis, trichomonaliasis or any other form of vulvovaginitis and pelvic congestion.

6. Patients having systemic illness like TB, diabetes, and hypertension etc.

Study design: Open level clinical trial

Table-1: Posology

\begin{tabular}{|l|l|}
\hline Type of Study & Single Group, open trial \\
\hline Period of Study & 90 days \\
\hline Drugs used & Shunti and Lodhra Churna \\
\hline Dosage & $\begin{array}{l}\text { Shunthi Churna (2 gms) + } \\
\text { Lodhra Churna (3gms) 3 } \\
\text { times a day after food }\end{array}$ \\
\hline
\end{tabular}

\begin{tabular}{|l|l|}
\hline Sahapana & Sharkara (5gms) \\
\hline Route & Oral \\
\hline $\begin{array}{l}\text { Anupana (mode of } \\
\text { drug intake) }\end{array}$ & With cold water \\
\hline $\begin{array}{l}\text { Observation During } \\
\text { treatment }\end{array}$ & $\begin{array}{l}\text { At an interval of 45 days till } \\
\text { the completion of trial } 90 \\
\text { days) }\end{array}$ \\
\hline $\begin{array}{l}\text { Follow Up Time After } \\
\text { treatment }\end{array}$ & $\begin{array}{l}\text { 2 consecutive menstrual } \\
\text { cycles after the 90 days of } \\
\text { treatment period }\end{array}$ \\
\hline
\end{tabular}

\section{Method of collection of data}

30 patients fulfilling the inclusive criteria were selected. Detailed history of patients was taken on predesigned specific proforma. History of present complaints with duration, associated symptoms, history of past illness (medical, surgical and drug history), personal history, menstrual history, obstetric history, contraceptive history were recorded. Other important points like marital status, socio-economic statuses were also noted.

\section{Investigations advised \\ Blood Examination:}

$\mathrm{Hb} \%$, Total leucocyte count (TLC), Differential leucocytes count (DC), Erythrocyte sedimentation rate (ESR), Platelet count, Bleeding time (BT) and Clotting time (CT).

\section{Urine Examination:}

1- For routine and microscopic examination and

2- For culture and sensitivity test.

Stool Examination: routine and microscopic examination.

\section{Ultrasonography:}

For condition of uterus and adnexae, any pelvic pathology and thickness of endometrium (ET).

\section{Assessment criteria}

Scoring of the symptoms was done before, during and after the study, purely on the basis of patient's explanations.

\section{A. Subjective Parameters}

Table-2: Showing the gradation of cardinal symptoms in the study

\begin{tabular}{|l|l|}
\hline Symptoms / Criteria & Score \\
\hline Amount of bleeding per menstrual cycle & \\
\hline $\begin{array}{l}\text { Complete soakage of }<3 \text { pads in 24 hours } \\
\text { (Average) }\end{array}$ & 0 \\
\hline $\begin{array}{l}\text { Complete soakage of 3-4pads in 24 hours } \\
\text { (Moderately excessive) }\end{array}$ & 1 \\
\hline $\begin{array}{l}\text { Complete soakage of 5-7 pads in 24 hours } \\
\text { (Excessive) }\end{array}$ & 2 \\
\hline $\begin{array}{l}\text { Complete soakage of or more than 7 pads } \\
\text { in 24 hours (Very Excessive) }\end{array}$ & 3 \\
\hline
\end{tabular}




\begin{tabular}{|c|c|}
\hline Symptoms / Criteria & Score \\
\hline \multicolumn{2}{|l|}{ Amount of bleeding per menstrual cycle } \\
\hline $\begin{array}{l}\text { Complete soakage of }<3 \text { pads in } 24 \text { hours } \\
\text { (Average) }\end{array}$ & 0 \\
\hline $\begin{array}{l}\text { Complete soakage of } 3-4 \text { pads in } 24 \text { hours } \\
\text { (Moderately excessive) }\end{array}$ & 1 \\
\hline $\begin{array}{l}\text { Complete soakage of 5-7 pads in } 24 \text { hours } \\
\text { (Excessive) }\end{array}$ & 2 \\
\hline $\begin{array}{l}\text { Complete soakage of or more than } 7 \text { pads } \\
\text { in } 24 \text { hours (Very Excessive) }\end{array}$ & 3 \\
\hline \multicolumn{2}{|l|}{ Duration of menstrual bleeding } \\
\hline Bleeding for $<5$ days (Normal) & 0 \\
\hline 6-7 days (moderately prolonged) & 1 \\
\hline 8-9 days (prolonged) & 2 \\
\hline$>9$ days (very much prolonged) & 3 \\
\hline \multicolumn{2}{|l|}{ Inter-menstrual period } \\
\hline 25-30 days (normal) & 0 \\
\hline 20-24 days (short) & 1 \\
\hline 15-19 days (very short) & 2 \\
\hline$<15$ days (highly abnormal) & 3 \\
\hline \multicolumn{2}{|l|}{ Pain during menstruation } \\
\hline No pain & 0 \\
\hline $\begin{array}{l}\text { Mild pain. Women complain of pain but } \\
\text { do not require any medication for relief }\end{array}$ & 1 \\
\hline $\begin{array}{l}\text { Moderate pain. Women complain of pain } \\
\text { and take one or two doses of drugs for } \\
\text { relief. The pain doesn't affect her routine } \\
\text { life }\end{array}$ & 2 \\
\hline $\begin{array}{l}\text { Severe pain, women complain of pain and } \\
\text { take } 3-4 \text { doses of drugs for relief. The } \\
\text { pain influences the general routine } \\
\text { activities }\end{array}$ & 3 \\
\hline \multicolumn{2}{|l|}{ Passage of clots } \\
\hline $\begin{array}{l}\text { No history of passing clots with menstrual } \\
\text { bleeding }\end{array}$ & 0 \\
\hline $\begin{array}{l}\text { Occasionally bleeding with clots (1-2 } \\
\text { cycles only) }\end{array}$ & 1 \\
\hline $\begin{array}{l}\text { Frequent clots but bleeding without clots } \\
\text { are also observed in few cycles in } \\
\text { between }\end{array}$ & 2 \\
\hline $\begin{array}{l}\text { Bleeding with clots in each menstrual } \\
\text { cycle }\end{array}$ & 3 \\
\hline
\end{tabular}

Table-3: Showing the gradation of associated symptoms in the study

\begin{tabular}{|c|c|c|}
\hline Associated Symptoms & \multicolumn{2}{|c|}{ Score } \\
\hline \multirow{2}{*}{ Angamarda } & Absent & 0 \\
\cline { 2 - 3 } & Present & 1 \\
\hline \multirow{2}{*}{ Daurbalya } & Absent & 0 \\
\cline { 2 - 3 } & Present & 1 \\
\hline \multirow{2}{*}{ Bhrama } & Absent & 0 \\
\cline { 2 - 3 } & Present & 1 \\
\hline
\end{tabular}

\begin{tabular}{|c|c|c|}
\hline \multirow{2}{*}{ Aruchi } & Absent & 0 \\
\cline { 2 - 3 } & Present & 1 \\
\hline \multirow{2}{*}{ Daha } & Absent & 0 \\
\cline { 2 - 3 } & Present & 1 \\
\hline \multirow{2}{*}{ Trusha } & Absent & 0 \\
\cline { 2 - 3 } & Present & 1 \\
\hline
\end{tabular}

\section{B. Objective Parameter: Hb\%}

Table-4: Showing the gradation of $\mathrm{Hb} \%$ in the study

\begin{tabular}{|c|c|}
\hline Hb \% & Gradation \\
\hline Normal (>11 gm \%) & 0 \\
\hline Mild (9-11 gm \%) & 1 \\
\hline Moderate (7-9 gm \%) & 2 \\
\hline Severe (<7 gm \%) & 3 \\
\hline
\end{tabular}

The values of both subjective and objective parameters were noted before, during (after 45 days) and after the treatment to assess the effect of therapy.

\section{Criteria to assess the results:}

- Cured: $100 \%$ relief

- Marked improved: More than 76\% relief

- Moderate improvement: $51 \%$ to $75 \%$ relief

- Mild improvement: $25 \%$ to $50 \%$ relief

- No improvement: $<25 \%$ relief

Table-5: Demographic observation of total registered patients $(n=30)$

\begin{tabular}{|c|c|c|c|}
\hline Observations & $\begin{array}{c}\text { Pre- } \\
\text { dominance }\end{array}$ & $\begin{array}{c}\text { No. of } \\
\text { patients }\end{array}$ & \% \\
\hline Age & $29-37$ yrs & 12 & 40 \\
\hline Habitat & Rural & 15 & 50 \\
\hline Marital Status & Married & 26 & 86.6 \\
\hline $\begin{array}{c}\text { Educational } \\
\text { status }\end{array}$ & High School \\
\hline $\begin{array}{c}\text { Socio-economic } \\
\text { status }\end{array}$ & Middle & 20 & 30 \\
\hline $\begin{array}{c}\text { Occupations } \\
\text { Class }\end{array}$ & House Wife & 19 & 63.3 \\
\hline $\begin{array}{c}\text { Dietary habit } \\
\text { Katu Rasa }\end{array}$ & 8 & 26.6 \\
\hline $\begin{array}{c}\text { Psychological } \\
\text { Status }\end{array}$ & Agitated & 15 & 50 \\
\hline Parity & Multi & 21 & 70 \\
\hline
\end{tabular}

\section{Results of Clinical Trial}

The effect of the treatment was analyzed statistically by calculating the mean, standard deviation, standard error, $t$ and $p$-values by using Paired t-test between the observations before treatment verses after 45 days of treatment and between the observations before treatment verses after the completion of treatment. 
International Journal of Ayurvedic Medicine, 2019, 10(1), 39-46

Table-6: Showing changes in cardinal symptoms before and during the treatment $(n=30)$

\begin{tabular}{|c|c|c|c|c|c|c|c|c|}
\hline \multirow[t]{2}{*}{ Chief complaints } & \multicolumn{2}{|c|}{ Mean } & \multirow{2}{*}{$\begin{array}{l}\text { Diff. (BT- } \\
\text { DT) }\end{array}$} & \multirow{2}{*}{$\begin{array}{c}\% \\
\text { Change }\end{array}$} & \multirow[t]{2}{*}{ S.D } & \multirow[t]{2}{*}{$\mathbf{S . E}$} & \multirow[t]{2}{*}{ 't' } & \multirow[t]{2}{*}{ p-value } \\
\hline & BT & DT & & & & & & \\
\hline Amount of bleeding & 1.76 & 1.16 & 0.6 & 33.9 & 0.63 & 0.08 & 6.7 & $<0.001$ \\
\hline Duration of bleeding & 1.93 & 1.23 & 0.7 & 36.2 & 0.55 & 0.08 & 8.36 & $<0.001$ \\
\hline $\begin{array}{l}\text { Inter-menstrual } \\
\text { bleeding }\end{array}$ & 1.93 & 1.3 & 0.63 & 32.7 & 0.64 & 0.08 & 7.19 & $<0.001$ \\
\hline Clots & 1.7 & 1.2 & 0.5 & 29.4 & 0.65 & 0.09 & 5.47 & $<0.001$ \\
\hline $\begin{array}{l}\text { Pain during } \\
\text { Menstruation }\end{array}$ & 1.63 & 0.96 & 0.66 & 40.8 & 0.65 & 0.09 & 6.79 & $<0.001$ \\
\hline
\end{tabular}

Table-7: Showing changes in cardinal symptoms before and after the treatment

\begin{tabular}{|l|c|c|c|c|c|c|c|c|}
\hline \multirow{2}{*}{ Chief complaints } & \multicolumn{2}{|c|}{ Mean } & \multicolumn{1}{c|}{$\begin{array}{c}\text { Diff. (BT- } \\
\text { AT) }\end{array}$} & \% Change & S.D & S.E & 't' & p-value \\
\cline { 2 - 10 } & BT & AT & A & & & & \\
\hline Amount of bleeding & 1.76 & 0.73 & 1.03 & 58.5 & 0.72 & 0.137 & 7.52 & $<0.001$ \\
\hline Duration of bleeding & 1.93 & 0.8 & 1.13 & 58.6 & 0.47 & 0.11 & 10.5 & $<0.001$ \\
\hline $\begin{array}{l}\text { Inter-menstrual } \\
\text { bleeding }\end{array}$ & 1.93 & 0.96 & 0.97 & 50 & 0.65 & 0.09 & 9.67 & $<0.001$ \\
\hline Clots & 1.7 & 0.9 & 0.8 & 47 & 0.65 & 0.1 & 7.29 & $<0.001$ \\
\hline $\begin{array}{l}\text { Pain during } \\
\text { Menstruation }\end{array}$ & 1.63 & 0.66 & 0.96 & 59.1 & 0.83 & 0.12 & 8.04 & $<0.001$ \\
\hline
\end{tabular}

Table-8: Showing changes in associated symptoms before and during the treatment

\begin{tabular}{|l|c|c|c|c|c|c|c|c|}
\hline \multirow{2}{*}{$\begin{array}{l}\text { Associated } \\
\text { symptoms }\end{array}$} & \multicolumn{2}{|c|}{ Mean } & $\begin{array}{c}\text { Diff. } \\
\text { (BT- DT) }\end{array}$ & \% Change & S.D & S.E & 't' & p-value \\
\cline { 2 - 9 } & BT & DT & & & & & \\
\hline Angamarda & 0.9 & 0.5 & 0.4 & 40.7 & 0.48 & 0.08 & 4.47 & $<0.001$ \\
\hline Daurbalya & 0.83 & 0.63 & 0.2 & 24 & 0.4 & 0.07 & 2.73 & $<0.05$ \\
\hline Bhrama & 0.73 & 0.5 & 0.23 & 31.8 & 0.42 & 0.07 & 3.02 & $<0.05$ \\
\hline Daha & 0.73 & 0.3 & 0.43 & 50 & 0.4 & 0.09 & 4.78 & $<0.001$ \\
\hline Trisha & 0.7 & 0.53 & 0.16 & 23.8 & 0.3 & 0.06 & 2.44 & $<0.05$ \\
\hline
\end{tabular}

Table-9: Showing changes in associated symptoms before and after the treatment

\begin{tabular}{|l|c|c|c|c|c|c|c|c|}
\hline \multirow{2}{*}{$\begin{array}{l}\text { Associated } \\
\text { symptoms }\end{array}$} & \multicolumn{2}{|c|}{ Mean } & \multirow{2}{*}{ Diff. (BT- AT) } & \% Change & S.D & S.E & 't' & p-value \\
\cline { 2 - 7 } & BT & AT & & & & & & \\
\hline Angamarda & 0.9 & 0.36 & 0.53 & 59.2 & 0.4 & 0.09 & 5.8 & $<0.001$ \\
\hline Daurbalya & 0.83 & 0.43 & 0.4 & 48 & 0.5 & 0.1 & 3.95 & $<0.001$ \\
\hline Bhrama & 0.73 & 0.36 & 0.36 & 50 & 0.5 & 0.09 & 3.66 & $<0.001$ \\
\hline Aruchi & 0.73 & 0.16 & 0.56 & 77 & 0.4 & 0.09 & 6.25 & $<0.001$ \\
\hline Daha & 0.7 & 0.43 & 0.26 & 38 & 0.4 & 0.08 & 3.29 & $<0.05$ \\
\hline Trisha & 0.7 & 0.46 & 0.23 & 33.3 & 0.4 & 0.07 & 3.01 & $<0.05$ \\
\hline
\end{tabular}

Table-10: Showing changes in $\mathrm{Hb} \%$ before and during the treatment

\begin{tabular}{|l|c|c|c|c|c|c|c|c|}
\hline & \multicolumn{2}{|c|}{ Mean } & \multirow{2}{*}{ Diff. } & \% Change & S.D & S.E & 't' & p-value \\
\cline { 2 - 7 } & BT & DT & & & & & & \\
\hline Hb \% & 9.8 & 10.0 & 0.2 & 2.3 & 0.5 & 0.74 & 2.49 & $<0.05$ \\
\hline
\end{tabular}

Table-11: Showing changes in $\mathrm{Hb} \%$ before and after the treatment

\begin{tabular}{|l|l|l|l|l|l|l|l|l|}
\hline & Mean & Diff. & \% Change & S.D & S.E & 't' & p-value \\
\cline { 2 - 8 } & BT & AT & & & & & & \\
\hline Hb \% & 9.8 & 10.5 & 0.75 & 7.68 & 0.6 & 0.11 & 6.76 & $<0.001$ \\
\hline
\end{tabular}


Overall Effect of Treatment:

Table-12: Distribution of patients based on Overall effect of treatment

\begin{tabular}{|l|c|c|}
\hline $\begin{array}{l}\text { Criteria to } \\
\text { assess the } \\
\text { results }\end{array}$ & $\begin{array}{c}\text { No. of } \\
\text { patients } \\
(\mathbf{n}=\mathbf{3 0})\end{array}$ & $\begin{array}{c}\text { Percentage } \\
(\mathbf{\%})\end{array}$ \\
\hline $\begin{array}{l}\text { No improvement } \\
(<25 \%)\end{array}$ & 0 & 0 \\
\hline $\begin{array}{l}\text { Mild } \\
\text { improvement } \\
(25-50 \%)\end{array}$ & 11 & 36.7 \\
\hline $\begin{array}{l}\text { Moderate } \\
\text { improvement } \\
(51-75 \%)\end{array}$ & 18 & 60 \\
\hline $\begin{array}{l}\text { Marked } \\
\text { improvement } \\
(76-99 \%)\end{array}$ & 0 & 3.3 \\
\hline $\begin{array}{l}\text { Cured } \\
(100 \%)\end{array}$ & 0 \\
\hline
\end{tabular}

The overall effect of treatment on the different symptoms stands out as we observed $60 \%$ of patients studied have improved moderately, followed by mild improvement in $36.7 \%$ of patients. We didn't observe any patients under no improvement category. We have observed only one patient (3.3\%) within marked improvement group but none in cured category.

\section{Results and Discussion}

Effect of therapy on Subjective parameters of Asrigdara:

\section{Cardinal Symptoms}

While analyzing the changes before, during (after 45 days) and at the end of the treatment period (90 days post-treatment) we observed that the amount of blood loss was reduced to $34 \%$ during and to $59 \%$ after the completion of treatment. Highly significant reduction was observed in duration of blood loss $36 \%$ during and $59 \%$ after) at the end of the treatment period. We observed an improvement by $33 \%$ during and $50 \%$ at the end in the inter-menstrual period. While analyzing the changes we observed reduction in passage of clots by $29 \%$ during and by $47 \%$ after the treatment. We also observed pain relief during menstruation by $41 \%$ during and $59 \%$ at the end of the treatment period in our treated patient groups (Table-2, 6-7).

\section{Associated symptoms}

In Angamarda, 41\% relief was found during and $59 \%$ after the treatment. In Daurbalya, 24\% relief was observed during and 48\% after the treatment. In Aruchi, $50 \%$ relief was observed during and $77 \%$ after the treatment. In Bhrama, 32\% relief was found during and $50 \%$ after the treatment. In Daha, 24\% relief was found during and 38\% after the treatment. In Trishna, 24\% relief was found during and $33 \%$ at the end of the treatment in our patients. The results were significant in most of the observations (Table-3, 8-9).

The observed values of TLC, DLC, ESR, BT, and CT, Platelet count, Urine and Stool examinations before treatment were within normal limits. Asrigdara is not an infective disease. So TLC, DLC, ESR, urine and stool examinations might have been normal. Excessive bleeding due to any coagulation disorders were kept in exclusion criteria, so only the cases having normal bleeding time, clotting time and platelet count were included in the study.

\section{Effect of therapy on objective parameter of Asrigdara}

Before, during and after the treatment period $\mathrm{Hb} \%$ was analyzed, and we observed highly significant improvement in the $\mathrm{Hb} \%$ after the end of the investigation period of treatment (Table-4, 10-11).

\section{Overall effect of therapy:}

The total effect of treatment in our treated patients, on the basis of criteria of assessment adopted, has shown that $60 \%$ of patients studied have improved moderately, followed by mild improvement in $36.7 \%$ of patients. We didn't observe any patients under no improvement category (Table-12). We have observed only one patient $(3.3 \%)$ within marked improvement category but none in cured category.

\section{Probable mode of action of the drugs in treating Asrigdara: \\ Shunthi:}

Acharya Charaka has explained Asrigdara is a symptom of Pittavrita A panavayu and A charya Sushruta mentioned it under Pitta samyukta Apana (16), Katu Rasa, Ushna Virya, Dipaniya, Vatanulomaka, Vibandha Nashaka (17, 18), properties of Shunthi helps to normalize the movement of Apana Vayu that has get obstructed by Pitta in the Artavavaha Srotasa. Due to Dipaniya and Pachaniya properties (19) it regularizes the function of Yakrita, hence metabolism of oestrogen becomes normal. So we hypothesized to see the positive effect in regulating the menstrual cycle and also the subsidation of symptoms like Ajirna, Aruchi (20) due to Amadosha Pachana.

Previous clinical research have shown that ginger, one of the forms of Shunthi can reduce symptoms of dysmenorrhea in some women when taken in a specific extract composition (Zintoma, Goldaru) (21). The extract of ginger blocks the formation of inflammatory compounds such as thromboxane, leukotrine and prostaglandins, thus acts as an anti-inflammatory substance (22). Hence, we believe this could have positive regulatory effect on dysmenorrhea. Due to antiinflammatory effect it is expected to pacify the pelvic congestion (high vascularity), thus the amount of blood loss gets reduced. 


\section{Lodhra:}

In the pathogenesis of A srigdara, Chala Guna of Vata Dosha, Sara and Drava Guna of Pitta Dosha (23) increases the amount of blood. Hence this drug might affect the Sara and Drava Guna of Pitta Dosha with the help of Ruksha, Laghu Guna and Kashaya Rasa (24, $25)$. So this could be the reason in reducing the amount of bleeding. Laghu, Ruksha Guna having Kapha-Pitta Shamaka (26) and Shoshana property (27)helps in Sroto Shodhana. Production of oestrogen is also increased by the use of fatty products in diet. Fatty materials have shown to increase the cholesterol in the blood circulation. Cholesterol is the precursor of all steroidal hormones; especially in female it is responsible for more production of oestrogen (28). Kapha Shamaka and Lekhaniya Karma are probably carried out by Laghu and Ruksha Guna (29) of Lodhra, therefore it decreases the production of oestrogen leading to reduced hyperplasia of endometrium.

Biochemically Lodhra contains 3monoglucofuronoside of 7-methyl leucopelagonidin, which makes it glycosidic in nature, which also exerts vaso-constrictive action and reduces the permeability of cell membrane. It has also shown anti-fibrinolytic activity. Ethanolic extract from bark also acts as an analgesic, anti-inflammatory and antioxidant (30). These properties are considered helpful in reducing the amount of bleeding.

Trishna results from the Rakta Kshaya i.e the loss of fluids from the body. Anaemic condition results in neuritis, which expresses itself as Daha. Due to Grahi Guna(vaso-constrictive action) of Lodhra is expected to have positive effect in curing Trishna and Daha by reducing the blood loss (31). It also pacifies Daha and Trisha due to its Sheeta Virya (32).

In a published in-vivo study, Lodhra has been shown to be useful and have an effect on regularizing menstrual cycle and also in ovulation (33). In another published report the effect of ethanolic extract of Symlocos recemosa bark powder in treating female reproductive dysfunction in a rat experiment showed significant decrease in the duration of pro-estrous phase and a significant increase in the duration of estrous, metestrous, diestrous phases (34).

Another report to test the hepato-protective effect of Symplocos racemosa Roxb, showed significantly reduction on the levels of hepatic enzymes and total bilirubin (35). In Asrigdara, Yakrita and Pliha get vitiated. So the hepato-protective activity (36) of Symlocos recemosa regulates the conjugation and metabolism of female hormones, which results in maintaining a normal menstrual cycle. Bhrama occurs due to blood loss, the haemostatic effect (Raktasrava nashaka of Lodhra might have effect in controlling Bhrama).

The main component of Lodhra is large amount of loturine alkaloid and it also contains à-spinosteral.
Spinosteral had been shown to have anti-inflammatory activity on isolated guinea pig ileum. It is suggested that Lodhra might have influenced the endometrial prostaglandin apparatus, thereby acting effectively in the control of dysfunctional uterine bleeding (37).

\section{Sharkara}

Due to Madhura Rasa, Sheeta Virya, Madhura Vipak $(38,39)$ Sharkara pacifies Pitta and Rakta, which is the main physiological factor in producing Asrigdara. Sharkara is very sweet and increases the taste, mitigates Vata, Pitta, Rakta, burning sensation, fainting, vomiting and fever (40). Madhura Rasa increases better palatability. Due to Madhura Rasa it acts as Balya, Bringhaniya, so the symptoms Daurbalya might have improved (41). It pacifies 'Raktapitta (42), Acharya Sushruta also mentioned Asrigdara to be treated just like treatment of Raktapitta. Because of its Sheeta Virya (43) property, it pacifies Daha, Trisha, and Raja. So it might have effect to normalize the abnormal menstrual cycle. Bhrama, Murchha etc. occur due to cerebral hypoxia resulting from the reduced oxygen carrying capacity of blood. Due to reduction in the amount of blood loss, it could have helped in curing Bhrama.

\section{Conclusion}

The main principle of the management of Asrigdar is deepana-pachana, Agni vardhana, rakta sthapana etc (44). Present research work was on the basis of observations and results of trial drug, pharmacological virtue and chemical constituents. The drugs Shunthi Churna and Lodhra Churna with Sahapana Sharkara possess Rakta Stambhaka Vatapitta Shamaka \& Vatanulomaka properties. Our tested drug combination has shown to be effective in excessive and prolonged bleeding by reducing both amount and duration of blood loss, normalizing intermenstrual period and also for relief in pain and improvement in consistency of blood. The drug combination also found to reduce the associated symptoms like Angamarda, Daurbalya, Aruchi, Daha, Bhrama and Trisha.

From the above findings and observations, we can conclude that the drug formulation Shunthi Churna and Lodhra Churna with Sharkara, proved to be effective in treating most of the symptoms of A srigdara.

\section{References}

1. Dutta DC. Text book of Gynaecology. Edited by Hiralal Konar, 5 ed. Calcutta; New central book agency; 2009. 183p.

2. Dutta DC. Text book of Gynaecology. Edited by Hiralal Konar, 5 ed. Calcutta; New central book agency; 2009. 79p.

3. Agnivesha, Charaka, Dridhabala. Charaka Samhita, Chikitsha Sthana, Yoni Vyapad Chikitsha, 30/209. Edited by Pt. Rajeswaradatta Shastry and Pt. 
Yadunandana Upadhyaya, Varanasi; Chaukhambha Bharati Academy; 2011. 868p.

4. Maharshi Sushruta. Sushruta Samhita, Sharira Sthana, Shukrashonita Shuddhi Sharira, 2/20. Edited by Kaviraja Ambikadutta Shastri, Varanasi; Chaukhambha Sanskrit Sansthan; 2009. 15p.

5. Robert W Shaw, W.P Soutter, Stuart L Stanton. Gynaecology. 3 ed. Churchill Livingstone; 2003. 464-465p.

6. Omran AR, Standley CC, Family Formation Patterns and Health. An International Collaborative Study in India, Iran, Lebanon, Philippines and Turkey. Geneva: World Health Organization. 1976; $335-372$

7. Omran AR, Standley CC, Family Formation Patterns and Health Further Studies. An International Collaborative Study in Columbia, Egypt, Pakistan, and the Syrian Arab Republic. Geneva: World Health Organization. 1981; 271 302

8. Telner DE, Jakubovicz D, Approach to diagnosis and management of abnormal uterine bleeding. Can Fam Physician. Jan, 2007; (53); 58-64

9. Agnivesha, Charaka, Dridhabala. Charaka Samhita, Chikitsha Sthana, Yoni Vyapad Chikitsha, 30/209. Varanasi; Chaukhambha Bharati Academy; 2011. $868 \mathrm{p}$.

10. Agnivesha, Charaka, Dridhabala. Charaka Samhita, Chikitsha Sthana, Yoni Vyapad Chikitsha, 30/115. Varanasi; Chaukhambha Bharati Academy; 2011.858p.

11. Agnivesha, Charaka, Dridhabala. Charaka Samhita, Chikitsha Sthana, Vata Vyadhi Chikitsha, 28/229. Varanasi; Chaukhambha Bharati Academy; 2011. $815 \mathrm{p}$.

12. Lakshmipati Vaidya Shastri. Yoga Ratnakara, Uttarardha, Streerogadhikar, Pradara Chikitsha, Shloka no-18. Edited by Bhisagratna Brahmasankar Shastri, Varanasi; Chaukhambha Prakashan; 2013. 396-401p.

13. Shree Madan Pal. Madanpal Nighantu, Shunthyadi Varga, Shloka no.3-4. Edited by Gyanendra Pandey. 1 ed. Varanasi; Chaukhambha Orientalia; 2012. $72 \mathrm{p}$.

14. Priya Vrat Sharma. Dravayaguna Vijnana, Triptighna Varga, Vol.2. Varanasi; Chaukhambha Bharati Academy; 2006. 617p.

15. Narahari Pandit. Raja Nighantu, Paniyadi Varga, Shloka no.104. Edited by Indradeva Tripathy. Varanasi; Chaukhamba Krishnadas Academy; 2010. 493p.

16. Maharshi Sushruta. Sushruta Samhita, Sharira Sthana, Nidana Sthana, Vata Vyadhi Nidanam, 1/37. Edited by Kaviraja Ambikadutta Shastri, Varanasi; Chaukhambha Sanskrit Sansthan; 2009. 299p.

17. Acharya Sodhala. Sodhala Nighantuh, Haritakyadi
Varga. Edited by R.R. Dwivedi. 1ed. Varanasi; Choukhambha Krishnadas Academy; 2009. 83p.

18. Vagbhata. Ashtanga Hridaya, Sutra Sthana, Annaswarupavijnaniyadhyaya, 6/163, edited by Brahmanand Tripathy. Delhi; Chaukhamba Sanskrit Pratisthan; 2009. 120p.

19. Kaiyadev. Kaiyadev Nighantu, Oushadhi Varga, Shloka no.1151-1152. Edited by Priya Vrat Sharma. Varanasi; Chaukhambha Orientalia; 2009. 213p.

20. Dhanvantari Nighantu. Shatapushpadi Varga, Shloka no.83. Edited by Priya Vrat Sharma. Varanasi; Chaukhambha Orientalia; 85p.

21. Natural medicines comprehensive database; www. Naturaldatabase.Com.

22. Gouda PR, Naidu ML. The effect of Ayurvedic drugs when used as disease-modifying Antirheumatic drugs in Amavata. Int. J. Res. Ayurveda Pharm. 2012; 3(1); 27-31

23. Agnivesh, Charaka, Dridhabala. Charaka Samhita, Sutra Sthana, Dirghanjibitiya Adhyaya, 1/59-60. Edited by Brahmanand Tripathy. Varanasi; Chaukhambha Surbharati Prakashan; 2010. 32p.

24. Srimad Bhav Mishra. Bhavprakash Nighantu, Haritakyadi Varga, Shloka no.215. Edited by G.S. Pandey. Varanasi; Chaukhambha Bharati Academy; 2013. 124p.

25. Dhanvantari Nighantu. Chandanadi Varga, Shloka no.156. Edited by Priya Vrat Sharma. Varanasi; Chaukhambha Orientalia; 119p.

26. Bapalal G. Adarsha Nighantu, Vol I.Varanasi; Chaukhambha Bharati; Reprint: 2007.

27. Priya Vrat Sharma. Priya Nighantu, Haritakyadi Varga, Shloka no.143. Varanasi; Chaukhambha Surbharati Prakashan; 2004. 33p.

28. Berg JM, Tymoczko JL, Stryer L. Biochemistry. 5 Ed. New York; W H Freeman; 2002, 26(4).1.

29. Agnivesh, Charaka, Dridhabala. Charaka Samhita, Sutra Sthana, Langhanbrihmniya Adhyaya, 22/12. Edited by Brahmanand Tripathy. Varanasi; Chaukhambha Surbharati Prakashan; 2010. 413p.

30. Bhusnar $H$ U, Nagore $D H$, Nipanikar $S U$. Phytopharmacological profile of Symplocos racemosa. Pharmacologia. 2014; 5(2); 76-83.

31. Kaiyadev. Kaiyadev Nighantu, Oushadhi Varga, Shloka no.1126. Edited by Priya Vrat Sharma. Varanasi; Chaukhambha Orientalia; 2009. 278p.

32. Narahari Pandit. Raja Nighantu, Pippalyadi Varga, Shloka no.212. Edited by Indradeva Tripathy. Varanasi; Chaukhamba Krishnadas Academy; 2010. $177 \mathrm{p}$.

33. Bhutani K Kr, Jadhav A N, Kalia V. Effect of Symplocos racemosa Roxb. on gonadotropin release in immature female rats and ovarian histology. Journal of Ethnopharmacology. 2004; 94; 197-200.

34. Gupta Santosh Kumar, Gupta Amit, Kumar Sokindar, Pandey prabhakar. Adaptogenic activity of Symplocos racemosa bark on female reproductive 
dysfunction in rats. International conference on global trends in pure and applied chemical sciences. Abstract published in $3^{\text {rd }}-4^{\text {th }}$ march 2012, Udaipur, Rajasthan, India.

35. Venkidesh R, Pal D, Ashok Kumar C.K, Saravanakumar A and Mandal SC. Hepatoprotective Activity of Symplocos racemosa Roxb. Bark Extract in Carbon tetrachloride induced Liver Damage in Rats. Int. $\mathrm{J}$ of Innovative Phamaceutical Research. 2011; 2(3); 147-150.

36. Wakchaure, D Jain D, Singhai AK and Somani R. Hepatoprotective activity of Symlocosrecemosa bark on carbon tetrachloride- induced hepatic damage in rats. J Ayurveda Integr Med. 2011; 2(3); 137-143.

37. Devi K P. Clinical evaluation of Pusyanuga Choorna and Lodhrasava in Raktapradara (DUB). Indian Journal of Traditional knowledge. 2007; 6 (3);429- 31

38. Priya Vrat Sharma. Priya Nighantu, Drava Varga, Shloka no.51. Varanasi; Chaukhambha Surbharati Prakashan; 2004. 236p.
39. Shree Shaligram, Shaligram Nighantu, Ikshu Varga, Khemraja Srikrishnadas Prakashan, Mumbai-4. 2011. 806p.

40. Srimad Bhav Mishra. Bhavprakash Nighantu, IkshuVarga, Shloka no.30. Edited by G.S. Pandey. Varanasi; Chaukhambha Bharati Academy; 2013. $780 \mathrm{p}$.

41. Agnivesh, Charaka, Dridhabala. Charaka Samhita, Atreyabhadrakapya Adhyaya, 26/42. Edited by Brahmanand Tripathy. Varanasi; Chaukhambha Surbharati Prakashan; 2010. 481p.

42. Maharshi Sushruta. Sushruta Samhita, Sharira Sthana, Dravadravyavidhimadhyaya, 45/168. Edited by Kaviraja Ambikadutta Shastri, Varanasi; Chaukhambha Sanskrit Sansthan; 2009. 236p.

43. Dhanvantari Nighantu. Shatapushpadi Varga, Shloka no.102. Edited by Priya Vrat Sharma. Varanasi; Chaukhambha Orientalia; 89p.

44. Pal M, Sharma P, Jain C M, Sharma S. Clinical study to evaluate the effect of Bolbaddha Rasa in Asrigdar. Int. J. Res. Ayurveda Pharm. Jan-Feb, 2016; 7(1); 53-56. 